\title{
Reflections on the Yoruba Past: Toyin Fa- Iola on Isaac Delano
}

\author{
Wale Oyedeji \\ University of Ibadan \\ waleayo60@gmail.com
}

\section{Introduction}

Toyin Falola remains one of the most illuminating voices with remarkable efforts to reposition the continent of Africa on the appropriate place on the global map. He has provided sufficient evidence that he deserves the accolades he attracts from contemporaries and admirers. More than many of his contemporaries, Toyin Falola continues to demonstrate that knowledge production from Africa is sustainable if past events are interrogated accordingly. In very many ways, he displays quality content that gives him the sort of image he has built for Africans generally, and himself particularly in the world of intellectualism. The debate about the essentialism of African knowledge economy, especially the Yoruba culture, is centuries old, and frozen in its condition. It became prominently popular from the beginning of African's contact with Europeans and Arabs, and this, ever since then, has attracted deepened engagement by African scholars whose primary intention was to defend their cultural legacy.

Understanding that the proliferation of such desecrating rhetoric that Africans are a people without history by Eurocentric scholars like Trevor Roper and David Hume was a consummate attempt to undermine their existence, and then justify their expansionist agenda, makes African scholars of various disciplines to stand in defense of their history, hence decolonization process in pre- and post-independence era. Apparently, it was Edward Said who asserts that, "domination and inequities of power and wealth are perennial facts of human society. But in today's global setting they are also interpretable as having something to do with imperialism, its history, its new forms." It thus seems that the generations that witnessed such unmistakable assault on their cultural heritage were not ready to accept it in good faith, and this provoked

1 Edward Said. Culture and Imperialism. New York: Vintage Books, 1993, p.19. 
corresponding resistance from them. They however reacted intellectually. It was in the spirit of reacting defensively that the first, second and third generations of historians emerged. Their sudden increase in the production of intelligent materials sent such a strong signal to the West so much that the world was compelled to change their erroneous misconception about Africa and Africans. As such, scholars like Samuel Johnson, Isaac Delano, Kenneth Dike, Bala Usman, Obaro Ikime, Bolanle Awe and a host of others took up the challenge of setting the record straight.

The trend continues in that fashion even in postcolonial environment. For one thing, it birthed the Ibadan School of History, an intellectual society that achieved beautiful and daunting results in their quest for African cultural redemption. Many contemporary scholars consider the efforts of these pioneer intellectuals purposely because their works provide sufficient background to understanding African cultures and values, its steady evolution and travails. As such, in this writing, I intend to consider the greatness of Yoruba culture, a people in West Africa, viz-a-viz their precolonial undertaking and their colonial experience. Leaning on the works of Isaac Delano, this work will look into the Yoruba past to reflect on the culture, philosophy, ideology, epistemology and ontology of the people, with a view to educating the general public on the inexhaustible items of their knowledge economy and productions. Falola has done exponentially well to relate to us the seemingly beautiful body of works produced by Isaac Delano in journals, newspapers, periodicals, personal records among many other things. All these are indications that ingenuity cannot be covered by the web of power because while power is transient, ingenuity that persists is not.

\section{Falola and the Aesthetics of Yoruba History}

There can never be any contention about the primacy of history in fighting cultural wars for history is useful in different folds and fora. First, we employ history as a potent instrument to empower people when the debate relating to their past and identity surfaces for deliberation or contention. Without adequate knowledge of history, it would be difficult to relate contemporary happenings with the past events, from which they could mirror, learn and devise the appropriate methods by which it could also be handled, deservedly.

Falola has always undertaken the duty of representing African historical legacies through an assortment of ideas and theories that are evaluated as useful to drive home his messages. For example, while Falola was relying on the narratives of Isaac Delano, he takes us into a historical adventure of Yoruba people with regard to how their philosophy of communalism was used to structure their society where values are preserved, ideas shared and 
thus the society maintained relative stability. For example, in one of the works of Isaac Delano, he relayed how the Egba people took a revolutionary stand against the domination of the Oyo supremacy, scheming methodically their own independence.

This becomes the standard for which the bravery and determination of the Yoruba people could be measured, and shows the beauty of unity as a method for fighting a general course. Falola unveiled the inherent philosophy that gives birth to such organized tactics devised by Lisabi, the heroic character in one of Delano's literary products, to challenge the hegemonic structure of the Oyo Empire. For one thing, this reveals that the Marxist-leaning Egba people were aware of the dangers of unchecked power, especially as affecting their economic and financial expansion. Ultimately, there is always the need for labor uprising whenever their productive power was undervalued, to prevent continuous encroachment by the superstructure. The debased labor force will resort to radical way-out or solutions, sometimes-mindless hostilities, in their quest for freedom in line with the Marxist ideology. Isaac Delano excavating this from the Yoruba history is motivated by the need to set the record straight and showcase the Yoruba people as a people with established philosophical constructs who are not only well-organized in their political and social philosophies in precolonial time, but also in the angle of their democracy where power was shared accordingly. In other words, these events are indications that there were existing social elements.

When there are indications that the central political system is already threading towards anarchy and anomie, the indigenous Yoruba people revolted by scheming approaches that would ensure their freedom. Apparently, this historical journey reveals the beauty of Yoruba past as having very many characteristics to share with an evolving society. People at every point in history use methods that would enhance their self-determination when they perceived injustices from their government establishment or realize that their growth could be threatened in the current political structure of an environment under which they are landlocked. This therefore presents to us the layers of struggles that underlie political affairs in the precolonial Yoruba environment, just like in every civilization. This recent history of the Yoruba people reveals that Africans of the past were not weaned of credible historical events from which they learn. Records are always beneficial when people dig into history and excavate events that would bring overwhelming advantages without necessarily having to deal with inferiority complex that comes when one's identity is debased. Falola's explanation of internal relations is grounded in the philosophical direction of Marxists. One notable characteristics of the disciples of Karl Marx philosophy is the idea that they reject in totality the dominance of the hegemonic power who build a relationship of master-subordinate 
with their subjects in order to keep them perpetually under repression. The Egba people were deprived of their economic values for example, the results of their labor were not forthcoming, and their resources were milked by the superstructure and would therefore need to find means to upturn this existing inequity to their own favor. Doing required that they take offensive measures to address the situation and the underlying risks were massive. They demonstrated a good level of coordination, tact and commitment to bring the situation under redress. This historical adventure became a source of education to people about the intricacies of power, as the quest for it comes with very compelling demands. Although the people of the Yoruba are understood as having a common ancestry, this does not however cancel the quest for supremacy. Therefore, power and political control is central to every socially evolving and philosophically developing group.

In another instance, one of the past histories of the Yoruba people was the involvement of Moremi, a matriarchy per excellence, in the evolution of IleIfe politics. Toyin Falola x-rays the contributions of this woman to understand the place of women in Yoruba world. Contrary to the general misconception that pre-colonial Yoruba was insensitive to gender equilibrium, the literary material of Isaac Delano educates us that the place of women in the development of the Yoruba society cannot be underplayed. Moremi, the wife of the King during her time was depicted as mentally sound, tactfully special and courageously outstanding woman. She was instrumental to the freedom of the people from a constant predation. While the people already surrendered their lives and properties to the invading power, Moremi, without the knowledge of anyone took to devising some methods through which they could bring the nagging situation to a halt. She schemed to volunteer herself for capture with the hidden intention to learn about the invaders' weaponry and know more about their strengths.

Truth to the ingenious power of the brave woman, she infiltrated the oppressive camp through some invidious means and secured a space for herself without giving chances to suspicion. Her intentions were not known during the time she was in their captivity and she explored her target unnoticed. After getting access to the opposition camp, she escaped from their ambush through a slim chance. Her safe arrival however would therefore mean that her community was freed from the fear of occasional invasion usually leading to loss of important possessions, most of which are their economy and farm produces. Through her efforts, the Ile-Ife people defeated their longstanding enemy, restoring peace to their land.

The beauty of this past event is to unfold the overwhelming importance of the women in the world of the Yoruba people. Yoruba culture and politics are laced with historical realities that validate the place of both genders 
in social development. In other words, there has been a level of gender democracy among them, where people are recognized for their contributions to the advancement of the society and not their sexual identity. On this basis, political positions are equitably distributed, social responsibilities are evenly defined and economic prosperity was not gender-based. The Ile-Ife people recognized this act of bravery with the erection of a statue to commemorate the valor of the outstanding woman. There are even festivals dedicated to her name as an appreciation of her emancipatory contributions during the trying times. Social development is understood as a network of activities by men and women who identify their place in social building and make strenuous efforts to influence generational changes. This reality defines the Yoruba world and are known for their impartial nature over gender identity. The history of Moremi confirms the assumption that Yoruba world prides itself in beautiful historical legacies.

Falola's research about Yoruba history is grounded in the understanding that history maps human society with appropriate events that can both be illuminating and philosophical at the same time. Historical events can be adequately illuminating because they provide humans with the knowledge of how to address similar issues when they emerge. For example, when the issues of reprisal attacks surface at any moment, people who are familiar with similar occurrence in the past rely on their experience to provide the needed light on how to handle the similar challenge. In this way, history is used as a weapon to face emerging challenges, making it easier to deal with. On the other hand, historical event can provide the background for formulation of noteworthy philosophy. Considering those series of experiences that Moremi on her expedition to safeguard the interests of her people in Ile-Ife faced, it forces a construction of social philosophy that gives room for gender respect and celebrates valiant engagements, regardless of people's gender identity. It would necessitate the people to develop a sense of altruism because of the understanding that it proves to come with desirable results. Even when people fail in their attempt to spearhead altruistic expedition that will lead to the emancipation of their people, they would attain a self-respect for themselves, provided the society does not recognize their input.

In a sense that Isaac Delano explained it, history becomes an identity formation event that shapes people's perception of the world. A Yoruba person identifies with the historical undertakings of the previous generations because such has created a deep sense of connection. Therefore, the essence of digging into history is to achieve two objectives. First is, the personal gratification that comes with the discovery that the past is not filled with degenerating image or activities as commonly suggested by European narratives in their usual habit for cultural colonization. Second, looking into African history has been 
helpful to fuel his interest in the pursuance of academic researches, shown in his writing, theories and social philosophy. Therefore, it cannot be downplayed that a journey into a people's past always comes with compelling benefits. The fact that the current world in filled with many successful women in the Yoruba culture attests to the inherent philosophical designs of the people's past which gives room for the two genders to write their names in gold as long as they are ready to make the sacrifice needed for it.

\section{Technologizing Yoruba Culture for Contemporary Relevance}

There is something concealing about the definition of culture as offered by Edward Said which therefore would not make it gain an access to this engagement. The fact that Said sees it as "a blend of indigenous activities with other invasive practices forming a hybrid after contact" ${ }^{2}$. This definition is time limiting, in addition to the fact that it sees culture as full-fledged materials that should not be tampered with. The persuasion of the definition gives too much credence to the now (present time) without especially looking at the distant history of human and social evolution process. Humans' culture, owing to the reality that they are formulated through continuous involvement in a particular activity, show why they are evenly dynamic. Although ideas are prone to change, they do so however with so minor change that it takes very long years to entirely notice a part of culture is evolving. On this premise, cultural activities like naming, dressing styles, marriage, festivals among other things absorb ideas as they evolve in order to gain a new outlook. For this, it is not uncommon to come across Africans, for example, to answer to European or Arabic names, wear foreign dress amidst other things, it is a process of evolution and does not determine the finitude of the culture.

Admittedly, cultural miscegenation is necessary especially as every culture comes with a quest for a change at a particular time. Forming a habit requires that certain knowledge of the environment is established because it is when such habit is consistent that it can be used as the basis for developing the human attitudes. Accordingly, cultures experience modifications at the right time when things take a different turn. Two fundamental things must be carefully considered as my argument progresses. One is that, culture is acutely misrepresented when humans consider their transient experience as the basis for defining it. The second and more important is, culture, like humans, is always in continuum of activities waiting to be updated with new experiences. In other words, it gets its outlook every time humans have a new experience.

Meanwhile what we consider as Yoruba culture, Igbo culture, European culture, are at a point in history contended heavily by the members of the

2 Ibid. 
public on the account that they are either not pleased with such change in lifestyle, or are not convinced of its necessity. In a plain language, culture could be that activity that enjoys consistent crusade from the group that is convinced of its essence, and used their power to enjoin other to participate in it, through available means, especially the media. When we say media, we mean all types of means by which people can get information across. In fact, humans can be seen as agencies of media through what they do, undo, engage in and disengage in among others. For example, when a king wears some patterns of dress, it becomes accepted by many people his community. Such proliferation emboldens the pattern of dress. If this is the case, what then would we get from the interest of Falola looking into history through the activities of Isaac Delano?

Falola, with his interest in cultural activism, comes into the picture because of his understanding that rather than exercise despair because of the domination of European culture industry on the world, Africans should study their culture to find ways by which it can be redefined and revitalized, to the extent that it will withstand the pressure coming from the Euro-American pressure. The proliferation of Westocentric ideas and culture stems from the understanding that modernity is tied to their innovations and technologies, making their activities compelling and, in some situations, difficult to repeal. This pressure to impose the European brand of modernity is therefore foreboding, leaving what Falola quoting Enweazor refers to as petit modernity ${ }^{3}$. It makes African helpless, if not hopeless, in their quest for self-realization and assertion. This is notably because it comes with the demand to sweep the indigenous cultures out of currency, impose theirs as the standard and ideal ones. Therefore, one who understands the political agenda of the imperialist culture would then accept that incubating one's culture to accommodate emerging trends is not a problem and should take the less interest or attention of the people. Instead, it should be weaponized. And then the question arises, how can this be weaponized?

The machinery of European modernity is predominantly driven by economic game-changing plan which they orchestrated. Through the Industrial Revolution that they premiered; they felt the need of pushing Western culture to the mainstream above every culture they came in contact with. The world experiences the gripping influence of European imperialism through the period of colonialism and this becomes the beginning for the mutation of different cultures, chief of which are African cultures. Trade, politics, ideological constructs are all tied to the embrace or importation of this "superior"

3 Toyin Falola. Cultural Modernity in a Colonized World. Austin: Pan-African University Press. 2020, P. 55. 
Western culture and the unprecedented ease of international and cross-geographical business makes it more confounding, or unobjectionable. Falola's historical engagement into the Yoruba past is underscored by his discovery that although it could be minimum, Western cultural praxis did not enjoy indigenous acceptance it has today by not mutating to accommodate existential practices from the colonized. They equally embraced change. In fact, a very good indicator of this is the transmogrification of missionary businesses to embrace local contents and systems. It is therefore believed that this method, the method of accommodation, aided the promulgation of Western culture into what we have today.

Therefore, the survival of the Yoruba culture as we have today would be determined by its ability to attract ideas and values that are alien to it, for the purpose of remaining in currency. Globalization has taught us in the hard way that pristine values that are not susceptible to change face one of these two options; one, go into extinction, and two remain inefficient even in the dictate of ideas and values to its basic custodians. A very good example of cultural legacy of the Yoruba people that analogizes this argument is the naming culture. It is common to find names among the Yoruba people with European inflections. Examples are Jésùfúnmi, Jésù冈eun, where the prefix, when morphologically disrobed, shows borrowed culture (and significance) as a possibility for cultural fusion, even in giving names. Whereas Yoruba understands that onomastic identity is crucial to the realization of the individual essence, their ability to transmute to accommodate structures that are alien to the culture shows that they not immune cultural modifications. Jesu, (the indigenous version of Jesus) as seen in the morphological operations in those names above, represents mutability, appropriated to reflect contemporary realities.

Something fundamental seems to be missing in this oversimplification, and it stems from the inadequate understanding of how massive a culture can be, especially when it is consciously used as a weapon. If people fear that, a change in culture will lead to the loss of their identity, how about the force of nature, could that also be challenged and won? This thinking therefore continues to delimit the African mind from making maximum use of their emerging realities to their advantage. It is this mindset that projects the European cultural landscape beyond their shores. By clinging onto their pristine cultures conservatively, Africans therefore unconsciously endanger their cultures. African cultural legacies would undoubtedly thrive when they maximize the underlying benefits of social structures and elements that came with colonization such as the importance of technology and global economy, to project their cultures across the world. In fact, the pioneer work to this is done by the generation of Isaac Delano and the fact that intellectuals like Falola came to the picture should make it easier. 
How then does the employment of technology help advance the cultures of the African people, especially the Yoruba to a desirable height? To answer this question, we must answer an important question, as this will enable us to understand why African cultures are not blended with contemporary realities. The question is, "what must have occupied the mind of the first European person who decided to embark on a journey of discovery of other civilizations apart from theirs"? Answering this question would shed needed light on the initial question. First, it is unarguably fundamental that man by his instinctual power desires that he colonizes his immediate environment for personal, if not provincial, reasons. Of course, sufficient information has surfaced that similar desire for imposition does not start with the European man. Precolonial Africans also engaged in geographical and economical colonization of others internally. What separates their desire however is that while one demonstrated the readiness to go beyond his geographical area, including seas and oceans, the other appeared to be contented with his proximal distance.

This creates an asymmetry of desires. And it cannot be seen as a challenge. However, there is a very useful knowledge we could draw from the zeal of the European man. His early start to the business of imperialism was wellplanned and appropriately pursued. For example, the literatures of the eighteenth, nineteenth and early twentieth century by English writers were used as the technology upon which they began their trade of colonialism. This enhanced their expansionist agenda. It assisted them to create a demographic of Europeans who already buy their narratives and automatically developed a sense of superiority, especially against a culture, people, civilizations they have never met, and most predictably, won't. This means that creating a situation that does not exist in the first place was a weapon used by the European imperialists to capture their victims to the extent that the colonized became defined by the narrative they weaved around them. Would it therefore come as any surprise, for example, that as at the time that Daniel Defoe penned down his classic masterpiece, Robinson Crusoe, he had never stepped his foot on the African continent?

Events around the world since the overtaking of African continent by the Europeans clearly have demonstrated that the human world is the ideological jungle where the survival of the fittest is the fundamental principle. So, when the giant European countries began the business of colonizing vulnerable civilizations using their own culture, in the sense that Edward means it in this context, their action could be mirrored by the activities of the lion in the animal kingdom. When the pride of lion roams the jungle, animals with lower capacity will remain vulnerable, and marginalized entirely from the politics of the jungle or progress. Through this understanding, Falola believes that African history, cultures and mores can be technologized in an attempt 
to compete for relevance and taking foreign cultural ideas would not be discarded outright as unimportant in a bid to getting their goals. Without losing our sweat, the events of the contemporary world have revealed that the superstructure is not in the business of imperialism for the fun of it, instead economic domination, cultural predation and epistemic struggles are used as means to remain in mainstream without challenges.

By arriving at this logical end, it becomes instructive to see how the reflections on the Yoruba past would enhance spiral development that the people deserve as an entity. For starters, Yoruba has a body of culture and history that becomes even more glamorous when it comes in contact with some other civilizations. This is because it believes that they could be used as agency to achieve their fullest potential. So, unlike some scholars who are defensively concerned about the survival of the African value system, Falola strongly believes that cultural activities are not preserved by guarding it against external miscegenation, however it is preserved when people make conscious efforts to preserve it. This therefore means that they would use the available resources to ensure that their need for cultural survival would be determined by a combination of activities which are including but not limited to their use of the media, education, creation of extant philosophy among other things. It is appealing therefore to know that the emergence of technology, the same products by the European engagements, can be a very positive sign that African cultures would thrive if they make appropriate use of them.

To do this, there must be a network of alliance between the intellectual community of the Yoruba people, their government, their masses and other stakeholders who would all stand their ground in the business of ensuring a longer time-span of their cultural heritages. This interrelationship is required because it would mean that everyone is on the same pedestal and the issue therefore would become a conscious business of the people generally. The man attaining western education would not suddenly turn his mind to his indigenous cultural practices to see them from another person's lenses as this would bring devastating consequences on the native culture because of the understanding that using another man's measurement for analyzing a practice, culture and philosophy is not a healthy way to preserve it. The government is needed to create some useful policies that would help develop the indigenous practices. There can never be contention about the power that the government wields in determining the cultural directions of a people. It is inbuilt in the government power to ensure this. The masses would be needed because they are the primary drivers of cultural legacy and its sustainability is tied to their involvement.

We are gradually getting to understand the place of cultural scientists like Isaac Delano and Toyin Falola in the business of diving into culture for the 
purpose or the survival of the Yoruba identity. Literary materials are, deservedly, conceived as technological inventions because they are used to spread the content written there beyond imaginable boundaries. At a very great speed, they transform the messages in them into physical substances that are therefore consumed by the people. The journey to this has therefore started with the works of Isaac Delano and it experiences an exponential expansion the moment scholars like Falola joins the emancipatory assignment. Therefore, the construction of educative material done by Delano decades ago aimed to achieve the goal of selling the Yoruba culture to the world in competition for survival and identity redemption was successful. Unlike Daniel Defoe, Delano did not deploy mudslinging narrative about another people he has no inkling about their existence. Rather, his energy was dedicated to representing the Yoruba culture by excavating them for preservation. The rate at which the culture would experience downtrend trajectory could have been unimaginable in the world where the Yoruba culture preserved in orality was not recognized.

Therefore, the idea of technologizing Yoruba culture has already been kickstarted the very time past scholars decided to use the writing technology to project these cultures. We must bring it to our notice, that using writing as a medium of projecting culture does not however stipulate that important aspects of the said cultures are not affected. This is owing to the reality that the writing custom cannot actually preserve some parts of the cultural heritages accordingly. There are consoling realities however that the medium has been very useful in not only preserving the Yoruba culture, it has also been instrumental to the global reckoning it has enjoyed within the relatively short period of beginning. For example, additional people would have understood that Yoruba people have confounding onomastic identity that signals important things about the people. This is in addition to the knowledge the public would have attained about other aspects of the culture. If these pioneers exercised doubt or fear about the possible adulteration of the Yoruba culture before launching their works in writing, the then popular technology, apart from the likely challenge of not being recognized as a people, it would have also limited their chances of seeing the world.

Going by this understanding, we should then think about how these cultures can be incorporated into the thriving contemporary technologies. Just as the culture did not bow out to others even by passing through the writing medium, the culture will survive and be re-branded. Even though the intellectual community has undertaken this challenge informally, their efforts have not been complemented by the activities of the government because of the obvious absence of policies that would enhance the sustenance of these cultural values. Our awareness should be drawn to the fact that education curriculum is not designed to reflect interest in cultural and indigenous heritages. 
This continues to threaten the advancement of the Yoruba culture because the people on whose shoulders lie the commitment to promote those cultural artefacts for survival are not well-equipped about their cultural history. The absence of this has necessitated the fact that they become victims of European programming that clearly undermines the survival of the African cultures. If the education of Yoruba does not cover their history and legacies to be inculcated in their younger ones between the ages of zero and eleven, it would remain the Achilles heels of the people.

It seems Africans are unaware of the dangers done to their cultures every time home videos with culturally desecrating contents are made to the detriment of their culture. The habit of desecrating African culture in an attempt for economic and financial expansion has been the core subjects of cultural survival and predation, aided by the unassuming African film producers. Today, there is the habit of negatively painting the African cultures for commercial reasons. What eludes Africans who are enmeshed in this engagement is that they are imperceptibly giving away their identity without being aware. The demoralization of the African heritages through imams and pastors in the Nollywood movies for example does not show the strength of the Western religion establishment, rather it erodes the values of Yoruba, and African, culture away to the extent that they would become victims of their own making when they lose identity in the general scheme of things. There are countless immoral undertakings and debasing cultural items existing in the European world that are always concealed by the European movie industry. This is because their cultural preservation takes important position in their environment and worldview. Apart from the gross misrepresentation of reality, even the form of image created in the Nigerian or African movie Industry is self-destructive.

Technologizing Yoruba culture is therefore premised on a principle of contention and strives in the jungle of human existence. It is the acceptance of this condition that would necessitate the development of right mindset to address the fear of possible extinction that people have about modernity. Even when the imposition of European modernity is not under any disguise, it does not however give room for playing victim card because this, rather than appeal to the emotion of the imperialist world, it gives them a sense of triumph over those people they already tagged inferior. The implication of bowing down to this hegemonic pressure means that Euro-American models of cultural principles will be pushed to the center, where others would be undeservedly reduced to function in the margin. We therefore would understand why the combinatorial influence of the intellectuals in Yoruba studies, the duo of Isaac Delano and Toyin Falola cannot be underwritten. By constantly employing the writing technology, they have already begun the work 
of technologizing African cultures for the purpose of preservation and valuation of these cultural practices at the same time. Simply put, what is needed now is the corroboration of their efforts in other fronts.

\section{Modernity as a Mirror of the Past}

It remains unassailable that the world moves in a cyclical direction. Ideas, practices and activities of the past have unpredictable ways of resurfacing, coming to life in a transformed status. There are expressed concerns about the nature of this rotational process of the world affairs, making some to see the world as a merry-go-round funfair where nothing is new as old things become recycled. Nearly all the events and activities of the modern time are mere new designs of old ones. What this explanation tends to reveal is the fact that ideas are always excavated from the existing ones for redefinition, recalibration and revitalization. That has been the pattern of evolution that happens in human world. For the fact that history, past actions and ancestral heritages are the background from which human draw information, knowledge and experience, it therefore reinforces the argument that those ideas are only reinvented to suit the modern arrangements.

It is rewarding to understand that Isaac Delano, alongside individuals of his literary generation, is produced by a culture of European imperialism that exerted colonialist ideologies on colonize people. This therefore has provoked a reality that they were products of hybrid cultures, making their access to true native ideologies difficult, and in some extreme cases, impossible. This however does not prevent indigenous cultures of the ex-colonized people from seeing the light of days, despite the intention of Orientals to irrevocably push their cultures to the margin. In the midst of overwhelming Eurocentrism - the use of European culture as the standard to which all other cultures are negatively contrasted ${ }^{4}$ - there are some aspects of Yoruba culture and values that are well-preserved, although not in the perfection of the uncontaminated nativity. Understanding the political consequences of allowing the imperial cultures to entirely sweep the indigenous ones to oblivion, those who acquired early the western education did extensive scholarly engagements to document their native heritages for continuous sustenance. Delano falls within this category and thus employed his literary works, the entire body of it, to set important cultural issues appropriately for common understanding, or education.

This comes from the quest of the formerly colonized people to demand for their past cultural activities that are not tainted by European values. Of

4 Tyson Lois. Critical Theory Today: A User-Friendly Guide. New York: Routledge, 2006 . 
course, this is what is tagged as decolonization and its process is long and arduous, demanding committed concentration from the people who underwent the torturous process of dehumanization, from colonialism. Therefore, the interest of Delano and the likes of Falola in looking into the past Yoruba history is to bring out those aspects of their culture to battle for space and relevance with the inherited colonial values. Critics such as Edward Said and Hommi Barber contend that the ex-colonized people are always faced with the suffocating temptation having to navigate their world using the European lenses. Perhaps they feel the compelling reason to challenge the status quo because their immersion into these European politics, values, ideologies and styles has rendered them the status of double identity, struggling intermittently to fix their psychological displacement that comes as a result of their contact with the West. By every means, the literature of people like Delano is tied to the reality that they would be guided by them to travel into their culture for their proper identity. Thus, the fact that their generation and the ones that follow them write about their culture means that they want to create a future that would be the reflection of their past and pristine values. We are constrained to consider some of these works, below.

In one of his usual ethnographic studies of the Yoruba people, Delano discusses the phenomenon of marriage in the Yoruba epistemology. According to him, marriage is the basic structure upon which the larger social structure is hinged, especially in the Yoruba worldview. ${ }^{5}$ The structuration of the society in this method is to ensure that the development of the Yoruba society is total and inclusive. Every individual understands their roles in the building of the social identity and values, and the understanding of this enables smooth running of events. It therefore creates a sense of responsibility and belonging to the level that people are really interested in how events are run by others because the breakdown in any chain affects the general system. In the spirit of social responsibility, people conceive marriage as important duty to offer contributions and accept in return some recognition offered in the form of gratification that comes with giving one's quota to the advancement of the system. This indigenous cultural configuration style is targeted by the European option that imposes itself as the primary standard for viewing such important thing as marriage. For the mere fact that these cultural practices are being subjected to function under the colonial ones gave it a more dehumanizing outlook.

African existence thrives on fusion of ideas, and the fact that some of their cultural practices as found in marriage reflects this opinion underscores the importance of communalism in their social build-up. Individuality as a social

5 Isaac Delano. An African Looks at Marriage. London: Lutterworth Press. 1944. 
philosophy is not considered worthy of practice and this gives an insight as to why social practices like marriage is conceived differently by the people. Without doubt, the idea of joining two individuals of unrelated family backgrounds together is premised on the need for strengthening of the social bonds, extension of cultural legacy and mores and the promotion and sustenance of their inherited cultural legacies. This has been the routine style among the people for many generations. However, the postcolonial Yoruba environment is now interspersed with various foreign styles that show their heavy immersion into colonial and imperial ideology, expressly confirming the fears of the ex-colonies about the adulteration of the culture. That is what encourages cultural icons like Falola and Delano to pave the ways for the restoration of these Yoruba cultural practices and principles, so that there would be arrangement for their input in the contemporary world.

In the exact words of Delano, the pristine Yoruba marriage is "a social duty, not merely a personal inclination or result of love between two people." 6 This present a case that is philosophically and ideologically different from the Western perception about marriage. An African marriage is seen as the ground to extend social interrelationship using the two individuals coming together as the agent of further unity. Clearly, the Yoruba conception of marriage is tied to the belief in the ancestral unity and collaboration, and physical ties are necessary for the promotion of some ideas of the society. It is this mindset that makes disrobing marital unity on the account of barrenness is a difficult, if not an impossible feat. Unless in the case where the husband is confirmed as impotent, marriage dissolution becomes very uneasy, if not condemned, to unbundle. By taking us to the idea of marriage therefore, this intellectual giant has done a great job to make us see that we can mirror modern development in line with the traditional values where social advancement and progression lie in the individual contributions of everyone to extend their collective values.

To the extent that the relationship between the newly wedded couple represents the social idea, the obligations expected from them ranges from conforming to cultural arrangements, commitment to religious philosophies, adhering to the social praxis among other things. This therefore sends a very strong message to the wedded couple that their relationship is not an inclusive engagement where they can be excused from the networks that solidify their communal togetherness. The society already takes a position that their union is bound to experience initial travails that underscore their newness to the business of relationships, and therefore assumes the roles of intermediary intermittently. This is needed because social breakdown is resident anytime

6 Ibid 
the society distances itself from the affairs of this couple. In essence, marriage goes beyond reproduction among the Yoruba people, and the lack of this knowledge pushes the European imperialists to conclude in a hurry that the culture of the colonized is actually demeaning, and incapable of being a model in the modern society. This conception of modernity imposes not only an attitude of arrogance to the imperial power, it also necessitated the colonized to adopt what postcolonial theorists refer to as mimicry ${ }^{7}$.

The overlapping influence of the past events on modernity however cannot be downplayed, given the unwholesome discovery that the characters that were used in the subsequent literary materials of Isaac Delano shows the exceeding influence of European cultures. In one of his masterpieces, Aiyé D’Aiyé Óyinbó, Delano through the character of Asabi, laments the influence of Europeans in changing the cultural landscape of the Yoruba people. Asabi begins, like a typical Eurocentric African apologist, to see the culture of polygamy for example as a corruption of moral architecture of the Yoruba because according to her, it was not an exercise that would enhance the sanity ${ }^{8}$ of the people as argued by some Yoruba cultural enthusiasts. She categorically declares her aversion to such custom when she says that "As for me, if I were a man, I would not marry more than one wife because I suffered much in the house of my father and in my husband's house especially in the hands of the other wives." 9 By this, the psychological victims of colonial ideologies now see their culture from the viewpoint of the Europeans because they have understood that the marriage culture of the white does not support polygamy.

The intelligence of Delano to mirror the event of the past in contrast with the contemporary experience of the colonized people is predictably founded on a conviction that people whose life is configured with the ideological constructs of the West would definitely exhibit Western cultures in their expressions and activities. However, the reality of monogamy can be more debilitating, in actual fact, than what obtained in the indigenous environment where polygamy was the usual practice. Adultery of unimaginable proportion, sexual perversions in unprecedented increase, the proliferation of sexual oddity, the normalization of morally deficient erotic behavior all are the nominal characteristics of the monogamy marriage system. What is however revealing through the insight of Delano is that majority of the postcolonial Africans are not grounded in their native cultures and therefore would view it from the lens of the foreigners. The philosophy behind this polygamy marriage structure is to prevent the tempers as identified in the above

7 Ibid

8 Isaac Delano. Aiyé D’Aiyé Òyinbó. Lagos: Thomas Nelson and Sons Limited. 1955.

9 Ibid 
consequences, delimiting and challenging the tranquility enjoyed in the pristine African societies. Monogamy comes with the philosophy of individualism and therefore precludes the contributions of the society members as found in the polygamous marriage.

Delano interrogates the past African cultures as a way to propose postcolonial reflections and insight into the events of history which can all be used to advance the contemporary courses of action. Yoruba world places important premium on marriage because it enables them to build important social structures from it. By the way of conjoining two people together, every member of the society becomes locked in a web of unity. Therefore, the care and social attention given to everyone in the society comes as a cultural configuration that is identified by the people to their own advantage. In this sense, culture is seen as a combination of many events, a system that operates and survives on the individual contributions for a common ground. Violations of these social constructs are locally punished, frowned at and condemned outright. It is remarkable therefore that intellectuals like Falola and Delano are taking confident steps to reveal the underlying good in mirroring Yoruba modernity, through their integration of pristine African cultures, as desirous modernity construct, not suitable for the inferior position that Western model of modernity has pushed others into. The awareness that past activities are not entirely distant from current reality is an igniting force that propels such thinking.

In this journey, the conception of modernity from the Western perspective, it seems, must take a different direction if Africans must really experience true modernity, for European modernity is filled with unmistakable imperialist hegemony. Given the reality that all the cultural practices of the ex-colonized are deemed unfit for consideration or attention, under the arrogant attitude of using and imposing Western cultural configurations as the appropriate standard. The demeaning consequence of this therefore can be spotted in the ways that psychologically conquered Africa began to see and measure themselves; the postcolonial Africans would consider European and American standard of modernity to pass judgement on theirs; this is no surprise because virtually all their cultural experiences are products of adulterations that are inspired by the Europeans. Even though cultural activists expressed doubts and worries over this uncanny reality, the highest they would do is to project the pristine African values in the form that they could access it. There is therefore the high probability that without bringing these untainted Yoruba cultural practices through the process of European-induced transformation, it would be further driven into oblivion by Western existential war.

Accordingly, there is nothing to serve as the powerhouse of cultural revolution except practices that we can access through either written documentation as done by the likes of Delano and Falola or their oral legacies as can 
be assessed by the "illiterate" Africans. The problem from this therefore is the probable disconnect between the intellectual community, the masses and the materials themselves. Not many people educated with Western models of education and their curriculum would understand the contextual values of their heritages. In fact, majority of the present Africans could hardly identify cultural practices that comes from their cultural background. This condemnable reality springs from the fact that they have been appropriately disconnected from their indigenous values. From marriage, to justice system, from political formations to the core social network, the indigenous cultural practices have been victims of marginalization and Western politics, making it more difficult to attain worthwhile attention. However, through vibrant and relentless efforts from the likes of these intellectuals, these cultural materials are brought to the fore for recognition and relevance.

\section{Yoruba Ontology: A Triumviral Unity of the Unborn, Born and the Dead}

We draw an inspiration from the fact that important personality such as Delano does not negate the position of the Yoruba people on so many topics. Despite his religious inclinations, he aligns with the understanding of his cultural background even to the consternation of his critics. Yoruba, like other people of the world, have their ontological explanations for virtually all the realities of life and they have held onto these things from time immemorial. Through the knowledge that is bequeathed by their ancestors, they understand the nature of the universe and how certain events are what they are. This knowledge therefore has been the basis of their religious, social, cultural, political and moral inclinations. They all work in harmonious relationship to bring about unique results in their quest for society structuring. The Yoruba world is so neatly knitted together with universal reality that one wonders how they came about their understanding of nature without actually having sophisticated materials to embark on truth finding. It is apparent that the emergence of science and its extant discoveries, many postulations of various religious and philosophical truths have been rendered by science as mere hypothesis. This however has not been the case with Yoruba's postulations and positions about the world.

This must be understood with the knowledge that every race of people usually create myth that they use in explaining some ambiguous things of nature. This is not limited to religious industries, there also are mythical things about science, believed by faith. Our argument about Yoruba and their ontology however stems from the reality that most of these positions held from time past are in harmony and agreement with the natural truths. This has been 
the reason for the success that Yoruba is recording their religious expansion today, in addition to their culture, that is thriving even in the world today, or has refused to bow out despite pressures from the external world. A journey of intellectuals into the past of the Yoruba people has always come with educative results because it is filled with mind-blowing discoveries. In what would be revealed momentarily, we would see how the understanding of the people about the connectivity of the physical world has always been with the world of the unseen. Ideally, one would expect that a culture that has not been into technological or scientific research found in the contemporary world has profound explanations for some natural events. Without considering the efforts of people like Delano, having access to beautiful information and education of these pristine African people may be somewhat difficult.

How the Yoruba conceive the nature of the world is the appropriate question to follow. However, it is worthy of understanding first what their ontology about the world actually is. First, we have the information that Africans generally believe in the triumviral unity of the living, and dead and the yet to the born too. In fact, this belief is stronger among the Yoruba people, and has been their guiding philosophy in doing good and admonishing that which is bad. Yoruba people believe that when individuals do good, they would be in peaceful condition with their physical and spiritual world. The spiritual world has overwhelming influence on the physical world because they have the manipulative and controlling contributions they provide to the physical world of man, according to Yoruba belief. This belief is etched in another social philosophy that emphasizes the importance of paying due obeisance to the elders and the dead because they are believed to possess the power to provide help when their services are required. Through this, the cord binding the people together becomes stronger, and their relationship is further strengthened. From the beginning of life to the present, the Yoruba people believe that everything is connected and experience has made them hold onto it without backing down.

At this point, it is important to consider the stand of Delano on something fundamental about knowledge and understanding of life generally. In one of his works, he says:

There was a time I regarded all what I found in the Bible, including the story of the creation, as the truth in spite of Darwin's theory which I had read when I was at College many years earlier. But today there is no point arguing just for the sake of argument. I became interested in Ifa as a literature many years ago and I found that its theory of creation is more 
confounded than the biblical one. Perhaps not all of us know the theory of creation as stated in Ifa. ${ }^{10}$

Something important is revealing from this confession credited to Isaac Delano. Implicitly, the cultural activist begins to develop such romance with Yoruba ontology and epistemology shortly after acquainting himself with this native knowledge. Earlier before this, he probably has paid a less attention to it because he must have been swept by the teachings and explanations of the Christian religion that has been his religious belief and background that dictates his philosophy. However, he shows that he is not a fundamentalist Christian because he is open to new ideas as long as they appear very logical and convincing. Disbelieving in the explanation of nature as provided by his religious faith does not however translate that he suddenly abandons the religion. Rather, it only gives him the assurance that those inherent postulations in his professed faith might have been the result of in-exposure to useful tools and technology to predict things after evaluation. But what is more confounding? It is the fact that he sees some logic in the explanation offered by the Yoruba people through Ifa. He does reveal how his journey into the study of Ifa has changed his perception of creation story and life also. Whereas it is through Ifa that the ontological explanation of the Yoruba world is given. And this is where it gets interesting. The vast knowledge economy of the Yoruba people is historically credited to Ifa which details the ontological perception of the people. Ifa establishes that the world of human as we know thrives on the harmonious relationship with the spiritual world, creating unity among everything that survives on the planet. Ifa teaches that there is absolute relativity between humans and ancestors (the dead), creating another unity with the unborn children. The ancestral existence and recognition supply human with the knowledge that the physical world is not the only thing there is. There are more than can be seen or said about the universe generally. We would need to hinge this explanation on some of the ones provided by notable scholars of Ifa and Yoruba knowledge economy. Clearly, Ifa reveals that the force of the ancestral existence is always in combination with the physical world, and through it they form an organic truth. The occupants of this phase of human existence are propitiated and appeased through rituals offered by those who are living. This is an attempt to woo the past in order that the future will be in good condition or predictable. ${ }^{11}$

10 Delano. Science Vs Religion.

11 Philip Neimark. The Way of the Orisa: Empowering Your Life Through the Ancient African Religion of Ifa. New York: Harper Publisher, 1993. 
The ontological design of the Yoruba, which Delano admirably consents to that he believes in its position on many things, favors the ancestors too because they are believed to wield unquestionable authority and power to affect the physical world. Therefore, it goes back to the relationship they create between their living, unborn and the dead people. Offering worships and deference to them is purposely done to be in peace with them and open the door of possibility of their intervention into one's life. The essence of this education is that Yoruba ontology differs in practice and philosophy with the Western styles and arrangements, and this means that they design their worldview to match this belief system. When ancestors are revered by the people, it does a wonder to the cultural theory of the people. The basic understanding that everyone who lives will die is a philosophy that springs from the ancestral worship which encourages people to maintain balance in their physical and spiritual life, and also make peace with themselves in the process. Rituals are given, their spirit appeased because it creates a harmony between the physical and the spiritual world.

In addition to this, the Yoruba world understands that the unborn also are part of the triadic life cycle that must be given appropriate recognition. They are the ones upon whose the legacy of living would be bequeathed. Without them too, it remains practically impossible to complete the circle of existence. Even though there are serial contentions about the truthful nature of this philosophy as there are usually growing difficulties in proving the reality of this pattern of existence with verifiable evidence, Neimark however puts the argument to rest when he asserts that "knowledge is what you really know in your heart or in your gut. It is not always logical, but it is totally real and true."12 What he means in this expression is that every knowledge does not follow the physical evidence of Western model and this does not disqualify its originality. Mr. A "knows" that he loves Mrs. B not because that idea of love he has comes from a logical background, but because he feels it in his body chemistry. The knowledge of ancestral existence and the concept of unborn children are given primacy among the Yoruba people because they feel there are instances that show their presence in their own world. The knowledge of the unborn children is interlaced with the concept of reincarnation and rebirth in the Yoruba world. Reincarnation, we must identify, does not really literally happen in the common usual sense. The idea of reincarnation in the worldview of the Yoruba has something to do with change in status, of the human soul into another human's body. Although this is not situated within any fixed understanding. There are some other modes of rebirth that happens through means like karma, or the transmutation into something entirely different. In

12 Ibid. 
short, the Yoruba world has been known for their ontology which is centered around the explanations that have been offered in this segment. Delano makes inward traces to his traditional ontologies and accept the underlying tempers of his native culture.

\section{Yoruba Concept of Justice}

The precolonial Yoruba people had a method of serving justice in their world before this became toppled by the Western justice system in the colonial and postcolonial era. Humans' activities are bound to create tensions and pressures when some parties are involved in conflicting engagements and this would therefore not lead to the outright extermination of groups just because their actions are deemed irrational. Humans who therefore break some regulations identified by the society and would be handled without any part, the offended and the offender, keeping additional grudges after social intervention through the available social interventions. Perhaps the best way to explain this method is by firstly putting into perspective human existence among themselves. Apart from the reality that there would always be tensions among rational beings, there is also a reality that these can be curbed if appropriate measures are put in place. People in the Yoruba world are seen as interconnected, and they are staunch believers that everyone is connected to one another through the intricacies of blood, genetic identity or cultural oscillation. People are not treated in isolation for they always bear the mark that would identify them with others, and this forms the basis of forming their justice system.

Internal strives and tussles are diplomatically handled. Unlike in the case of the Western justice system where severe punitive measures are reserved for law offenders, which in some extreme cases may lead to their crucifixion depending on the severity of their offence. Yoruba world is unconvinced that the total obliteration should become the end of an individual no matter how grave their offences are. The argument that the absence of capital punishment would encourage more social vices does not hold in the Yoruba worldview because two wrongs to them do not make a right. It is believed among them that individuals can be discouraged from engaging in decadent moral behavior through the fecundity of the philosophy they practice in the society generally. It will be somewhat illogical in Western society because their foundation of justice is hinged on a different structure, or philosophical construct that could only thrive in their type of environment. Ever since the incursion of the West, with their imposing frame on their colonies' educational structure, and other important areas like justice and religion, the people have taken a level of distance from the native methods of education, justice and religion, respectively. 
Either this has gone to create an eruption of conflict can only be judged by the eventual reality of these people after shortchanging indigenous styles and practices for the existing ones. For one, the advent of the Western justice system has not, and most predictably would not, curb social and moral delinquency. Instead, it has somewhat contributed to its increase. The reasons for this can be predicted. Africans are very good at manipulating external systems for their benefits, knowing that the existing indigenous measures are difficult to maneuver. Starting from the foreign method of administering politics, the postcolonial African nation-states are difficult to surpass in corruption cases just because they can easily manipulate these systems. Many cases in the court of law are condemned to silence, or abandonment in as much as personalities could afford the price of justice. This means, implicitly, that justice can be bought in the postcolonial Africa as long as one can pay the price. Delano's romance with the African/Yoruba past begins after carefully studying the indigenous practices and how they are hardly susceptible to parochial manipulations.

All the cultural symbols are useful in ensuring justice and always demand conformity from those who are sworn to protect the interests of the masses. The fact that every individual in the society is aware of the indexical values of these symbols used in available social institutions, they attune themselves to the moral dictates of the society, without struggling to finding how they could be breached. The breakdown of laws, values, morals and mores prevalent in the postcolonial Yoruba society is traceable to the inherent weakness of the Western philosophical constructs that have been adapted and adopted by the people of the modern environment. A political leader for example that is sworn in for an official duty through the indigenous methods will reflect very deeply before abusing his office for selfish interest. He would understand the connectedness of his actions to the general well-being of the society. Because the Yoruba people take great interest in the affairs of everyone, whatever each individual does always has a way to influence the lifestyles of others. It is an intricate unity that has been confirmed to work in their own environment. Justice in the pristine time was not commodified, the contrast drawn in L'Ó jọ Ojọ́ $U n^{13}$ by Delano explains this further.

\section{Conclusion}

To an extent that I have addressed important questions about the place of Yoruba values and ideas in the contemporary world, I have considered Falola's interest into the past Yoruba custom through the intellectual engagements of Isaac Delano, as the major driver of my contributions. Without doubt, Falola

13 I. O. Delano. L'Ọ́ jọ́ Ọjọ Un. Lagos: Thomas Nelson and Sons Limited, 1959. 
stands out among postcolonial Nigeria authors and minds in his commitment to ascertain that the Yoruba cultural configurations do not remain the victim of mudslinging which the non-Africans have continuously sought to lead it, forever. Clearly, the first victim of colonization is the history of Yoruba and African people which were supplanted by the Europeans by their image-denting narrative, doing the twin business of misrepresentation and misinformation, at the same time. This is despite the fact that the people have beautiful historical legacies that are worthy of memory and reverence. The realization that if African histories are allowed to thrive in the process of their exploits and after it, it would quickly enable them to expunge the Western ideas and as such would impede their elongated domination, necessitated this. How then did they choose to address this likely situation? They have their histories and narratives dominate the African life so compelling that some Yoruba people lose the track of their ancestral systems.

However, people like Delano and Falola, in addition to other body of African cultural activists, continue to challenge this structure with strong evidence that their past is not splattered with unwholesome practices as projected by the West and unquestionably accepted by the people. There are admirable cultural legacies which could in the long run attract worthy attention, and they could also be transmitted into technology for wider access. The duo of Delano and Falola have thoughtfully analyzed how this could be done without losing important things about their culture in the long run; something which has been the fear of conservatives in their thoughts that leveraging on the promulgation of technology would only have negative results. These people do not share this sentiment as they are really convinced that not making use of the opportunities provided by technology would instead lead to the fast erosion of these values, as they calculate that this generation of postcolonial world may not possess such a reliable memory to preserve the culture of their forebears. Even if they could, these people estimate that it brings no harm if they use the available means, technology, to achieve the same goal. This is because using technology is not an end in itself, it is a means to an end.

Invariably, we have got to the point where we need to harmonize the thoughts and convictions of Peter Ekeh who understands that colonialism was not without its attendant favorable sides for African countries ${ }^{14}$. Contrary to the longstanding tension initiated and sustained by the closeted cultural conservatives who were, in the quest to be culturally self-assertive, close their eyes to the creation of structures and the reinstatement of various colonial frameworks that is the foundation of numerous practices in Africa; democ-

14 Peter Ekeh. Colonisation and Social Structure. Ibadan: Ibadan University Press,1983, p.8. 
racy, social institutions, urbanization and a host of others. Considering the fact that technology is the brainchild of European expansionist agenda, a legacy of imperialism, and given the reality that Africans have remained on the rocky spectrum and foundation of social structures, such as mentioned above, without "decolonization" of them, technology (like these inherited structures) can be used to project African worldviews and cultural essence to integrate themselves into the body of fast-changing universe, and then claim for themselves an identity that holds important stake, in the world generally. Borne out of the reality that pristine ideas and cultural connotations cannot be redacted into its original form, and this should not be a cause for alarm, for nature is an ever-changing entity.

In conclusion, Delano has done extensively well by subtly commanding our attention to the social transformation demands that need the involvement of intellectuals as well as every reasonable African. And Falola has corroborated this by revealing history to us because he understands the inexhaustible advantage of using history in the right way to redirect the people from ceremoniously towing the wrong direction. Therefore, we, as co-performers in the drama of cultural redefinition, are meant to handle the aspect of reflections into the past through the available materials these people have provided for us so that the postcolonial Yoruba environment and society would not be enmeshed in the game of finger-pointing, while their future becomes short-circuited by frenzy of modernism, the result of which will not only be devastating to their advancement, but also will necessitate outright identity displacement. And this will be disastrous. Of course, decolonization is still an underway project, but with the assertive influence of colonial machinations and their machineries, it is not out of place that ex-colonized spaces cannot achieve true extermination of colonial experiences because their encounter with Africa has enforced institutional continuities and social restructuring, which arguably does not come as an imported magma from European enclave, rather they emerged as the result of fusion of the two civilizations.

\section{Work Cited}

Ekeh Peter. Colonisation and Social Structure. Ibadan: Ibadan University Press. 1983.

Falola Toyin. Cultural Modernity in a Colonized World: The Writings of Chief Isaac Oluwole Delanọ. Austin: Pan-African University Press, 2020. Delano Isaac. Aiyé D’Aiyé Òyìnbó. Lagos: Thomas Nelson and Sons Limited. 1955.

Delano Isaac. L'Ớ jọ́ Ojọ́ Un. Lagos: Thomas Nelson and Sons Limited, 1959. 
Delano Isaac. An African Looks at Marriage. London: Lutterworth Press. 1944.

Lois Tyson. Critical Theory Today: A User-Friendly Guide. New York: Routledge. 2006.

Naimark J. Philip. The Way of the Orisa: Empowering Your Life Through the Ancient African Religion of Ifa. New York: Harper Publisher, 1993.

Said Edward. Culture and Imperialism. New York: Vintage Books, 1993. 